\title{
Kahramanmaraş linin Tarımsal Mekanizasyon Düzeyinin Haritalanması ve Değerlendirilmesi
}

\author{
Tayfun KORUCU ${ }^{1 *}$, Ali AYBEK ${ }^{1}$, Fatih S VR KAYA ${ }^{2}$, Enes GÜRLEK ${ }^{1}$, Cengiz MERT $^{1}$, Begüm KOZAK ${ }^{1}$ \\ ${ }^{1}$ KSÜ, Ziraat Fakültesi, Biyosistem Mühendisliği Bölümü, Kahramanmaraş \\ ${ }^{2}$ KSÜ, Orman Fakültesi, Orman Mühendisliği Bölümü, Kahramanmaraş
}

Geliş (Received): 16.01.2015

Kabul (Accepted): 27.04.2015

ÖZET: Bu araştırmada; TUIK verileri kullanılarak, 2008-2013 yıllarında Kahramanmaraş ilinin ilçeleri bazında ve il genelinde, tarımsal mekanizasyon düzeyi gösterge değerleri $(\mathrm{kW} / \mathrm{ha}$, traktör/1000 ha, ha/traktör, aletmakine/traktör, $\mathrm{kW}$ ) belirlenmiş, bu gösterge değerlerinin yersel değişim haritaları ve grupları oluşturularak değerlendirilmiştir. 2008 ve 2013 yılları TUIK verilerine göre Kahramanmaraş ilinin toplam traktör sayısı 10 56112165 adet olup ortalama traktör gücü değerleri $41.5-40.59 \mathrm{~kW}$ dır. Üretim alanları değerleri 366 251-359 578 ha ve tarım alet-makine sayıları ise 48 734-62 848 adet'tir. Kahramanmaraş ilinin mekanizasyon düzeyi gösterge değerleri ortalaması, $1.21-1.37 \mathrm{~kW} / \mathrm{ha}, 28.84-33.83$ traktör/1000 ha, 34.68-29.56 ha/traktör ve 4.61-5.17 aletmakine/traktör'dür. Türkiye 'nin mekanizasyon düzeyi gösterge değerleri ortalaması ise $1.98-2.37 \mathrm{~kW} / \mathrm{ha}$, 44.02-52.23 traktör/1000 ha, 22.71-19.15 ha/traktör ve 5.28-5.09 alet-makine/traktör'dür. 2013 verilerine göre Kahramanmaraş ili ilçeler bazında değerlendirildiğinde; birim alana düşen traktör gücü bakımından en yüksek değere $2.97 \mathrm{~kW} / \mathrm{ha}$ ile Andırın, en düşük değere ise $0.76 \mathrm{~kW} / \mathrm{ha}$ ile Göksun ilçesi sahiptir. 1000 ha alana düşen traktör sayısı bakımından 79.49 traktör/1000 ha ile Çağlayancerit en yüksek, 22.37 traktör/1000 ha ile Göksun ilçesi en düşük değerlere sahiptirler. Traktör başına düşen tarım alanı bakımından en düşük değere $12.58 \mathrm{ha} /$ traktör ile Çağlayancerit ve en yüksek değere 44.70 ha/traktör ile Göksun ilçesi sahiptirler. Traktör başına düşen alet-makina sayısı (alet-makine/traktör) dikkate alındığında en yüksek değere 6.45 alet-makine/traktör ile Pazarcık, en düşük değere ise 2.55 alet-makine/traktör ile Çağlayancerit ilçesi sahiptir.

Anahtar kelimeler: Tarımsal mekanizasyon düzeyi, yersel haritalama, Kahramanmaraş

\section{The Mapping and Evaluating of Agricultural Mechanization Level of Kahramanmaras}

ABSTRACT: In this study, using data from TUIK (Turkish Statistical Institute) for the years 2008-2013, indicators of agricultural mechanization level ( $\mathrm{kW} / \mathrm{ha}$, tractors $/ 1000 \mathrm{ha}$, ha/tractor, equipment-machine/tractor, $\mathrm{kW}$ ) have been summarized for the Kahramanmaraș province and its districts as a whole. Spatial maps and groups of change have been established and evaluated. Total tractor numbers and the mean tractor power for Kahramanmaraş were respectively $10561-12165$ and $41.5-40.59 \mathrm{~kW}$ for the years 2008 and 2013. Total cultivated area were 366251 359578 ha and the quantity of equipment was also 48 734-62 848 for the years 2008 and 2013. Kahramanmaraş 's agricultural mechanization indicators were 1.21-1.37 kW/ha, 28.84-33.83 tractor/1000 ha, 34.68-29.56 ha/tractor and 4.61-5.17 equipment/tractor. Turkey's agricultural mechanization indicators were also 1.98-2.37 kW/ha, 44.02-52.23 tractor/1000 ha, 22.71-19.15 ha/tractor and 5.28-5.09 equipment- machine/tractor for the years 2008 and 2013. According to the TUIK data base for the year 2013, the tractor power per unit of cultivated land was the highest in Andırın district $(2.97 \mathrm{~kW} / \mathrm{ha})$ and the lowest in the Göksun district $(0.76 \mathrm{~kW} / \mathrm{ha})$. The highest and the lowest values for number of tractors per unit of 1000 ha cultivated land were respectively in the Çağlayancerit district with 79.49 tractors/1000 ha and in the Göksun district with 22.37 tractors/1000 ha. The amount of cultivated land per tractor was the lowest in the Çağlayancerit district (12.58 ha/tractor) and the highest in the Göksun district (44.70 ha/tractor). The quantity of equipment per each tractor (equipment-machine/tractor) ranked the highest in the Pazarcık district (28.66 equipment-machine/tractor) and the lowest in the Çağlayancerit district (5.55 equipmentmachine/tractor).

Keywords: The agricultural mechanization level, spatial mapping, Kahramanmaraş

\section{G R Ş}

Günümüz tarımsal üretimin temel amaçlarından biri, birim alandan niteliksel ve niceliksel olarak daha yüksek üretim sağlamaktır. Tarımsal mekanizasyon, tarımda ileri teknolojilerin uygulanmasını, ayrıca toprak, su, gübre, ilaç, vb. girdilerin etkin kullanımını olanaklı kılarak, verimliliği sağlayan önemli bir üretim aracıdır. Gelişmiş ülkelerin tarımda, verimlilikte, sağladığı gelişmelerin tümünde mekanizasyon anahtar rol oynamıştır. Küresel rekabet ortamında bu rol giderek artan önemle sürecektir (Evcim ve ark., 2010). Tarımsal mekanizasyon, yüksek maliyetli bir üretim girdisidir. Genel olarak bir tarım işletmesinde arazi giderleri hariç, toplam üretim giderlerinin \% 6'sını kimyasallar, \%10'unu tohum, \%10'unu gübre, \%11'ini işgücü, \%13'ünü diğer giderler ve \%50'sini de mekanizasyon oluşturmaktadır (Anonim, 1999). Bu nedenle tarım işletmelerinde, mekanizasyon girdisinin

*Sorumlu yazar: Korucu,T., tkorucu@ksu.edu.tr 
en ekonomik şekilde kullanılması için yöresel koşullara uygun planlama modelleri oluşturulmalıdır (Toğa, 2006).

Tarım işletmelerinin verimliliğinde önemli yer oluşturan mekanizasyon uygulamaları, her üretim sezonu sonunda mutlaka bilimsel esaslara dayalı olarak değerlendirilmelidir. Bunun temel amacı, aynı bölge sınırlarında veya farklı ülkelerde benzer üretim koşullarında çalışan işletmelerin mekanizasyon uygulama yoğunlukları ve etkinlikleri açısından karşılaştırmalarına olanak sağlamasıdır (Say ve ark., 2010).

Tarım işletmelerinin, yörelerin veya ülkelerin tarımsal mekanizasyon düzeylerinin belirlenmesinde ve karşılaştırılmasında birçok gösterge değeri kullanılmaktadır. Yaygın kullanılan tarımsal mekanizasyon düzeyi göstergeleri aşağıda sunulmuştur (Sabanc1 ve Akınc1, 1994; Zeren ve ark., 1995; Anonim, 2000; Dartar, 2007; Ergüneş ve ark., 2009; Say ve ark., 2010).

- şlenen alana düşen traktör gücü $(\mathrm{kW} / \mathrm{ha})$

- 1000 ha işlenen alana düşen traktör sayısı (traktör 1000/ha)

- Traktör başına işlenen alan (ha/traktör)

- Traktör başına alet/makine sayısı (aletmakine/traktör)

Kahramanmaraş ili, Türkiye'nin Akdeniz Bölgesi ile Doğu ve Güney Doğu Anadolu Bölgelerinin geçiş sahasında bulunur. lde Kahramanmaraş, Elbistan ve Göksun Ovaları ile bir çok su kaynağı bulunmaktadır. Kahramanmaraş, verimli geniş üretim alanları, akarsu potansiyeli ve uygun iklim özellikleri ile tarımsal üretimde önemli bir yer tutmaktadır. Yörede tahıllar, baklagiller, endüstri bitkileri, yağlı tohumlar, yumru bitkiler ve yem bitkileri yanında sebze ve meyve üretimi de önemli bir yer tutmaktadır (Ozan, 2001; Anonim, 2014).

Günümüze kadar, Kahramanmaraş ilinin tarımsal mekanizasyon düzeyinin belirlenmesine ilişkin çalışmalar yapılmıştır (Elmas ve ark., 1995; Atay ve Işık, 1997; Aybek ve Hurşitoğlu, 2002; Aybek ve Şenel, 2009). lde, ilçeler bazında ve yıllar itibariyle yapılan herhangi bir çalışma bulunmamaktadır. Ayrıca işletmelerde mekanizasyon yapısının belirlenmesine yönelik çalışmaların, değişim süreci çerçevesinde ve belirli zaman dönemlerinde yinelenmesi, üretim planlaması politikalarına yardımcı olacaktır.

$\mathrm{Bu}$ çalışmada, 2014 TUIK verileri kullanılarak; 2008-2013 yıllarına ait Kahramanmaraş ilinin ilçeler bazında; tarımsal mekanizasyon düzeylerinin belirlenmesi, bu düzeylerin yersel değişim haritalarının ve gruplarının oluşturulması, elde edilen sonuçların değerlendirilmesi amaçlanmıştır.

\section{MATERYAL ve YÖNTEM}

Kahramanmaraş ili ve Türkiye'nin genel ortalamasına ilişkin tarımsal mekanizasyon düzeylerinin belirlenmesinde, 2008-2013 yıllarına ait istatistiksel veriler kullanılmıştır. lgili değerler, Türkiye statistik Kurumunun veri tabanındaki "Bitkisel Üretim statistikleri" ve "Tarımsal Alet ve Makina Sayıları" sekmeleri kullanılarak elde edilmiştir (TUIK, 2014). Alınan veriler; üretim alanları (Çizelge 1), traktör ile çekilen tarım alet/makine sayıları (Çizelge 2), traktör sayıları (Çizelge 3) ve traktör güçleridir (Çizelge 4).

Çizelge 1. Kahramanmaraş ili ve Türkiye'nin 2008-2013 y1llarındaki üretim alanları

\begin{tabular}{lrrrrrr}
\hline & \multicolumn{5}{c}{ Üretim alanı (ha) } \\
\cline { 2 - 6 } lçeler & \multicolumn{1}{c}{2008} & 2009 & 2010 & 2011 & \multicolumn{1}{c}{2012} & 2013 \\
\hline Merkez & 65326 & 66344 & 64782 & 62338 & 58045 & 55330 \\
Afşin & 44298 & 51080 & 53751 & 58168 & 53028 & 61671 \\
Andırın & 20410 & 20271 & 21820 & 22682 & 14858 & 18813 \\
Çağlayancerit & 9667 & 9368 & 8821 & 5118 & 5696 & 4026 \\
Ekinözü & 7112 & 6835 & 6991 & 5815 & 5822 & 6224 \\
Elbistan & 99549 & 76712 & 80687 & 99924 & 79657 & 100732 \\
Göksun & 46327 & 44433 & 45049 & 44820 & 44262 & 40852 \\
Nurhak & 4990 & 4099 & 2973 & 3275 & 3115 & 3154 \\
Pazarcık & 47105 & 52871 & 53579 & 54597 & 44419 & 49699 \\
Türkoğlu & 21468 & 20412 & 19857 & 18576 & 13604 & 19079 \\
\hline Kahramanmaraş & 366251 & 352426 & 358309 & 375312 & 322506 & 359578 \\
\hline Türkiye & 24407354 & 23882190 & 24394205 & 23613761 & 23781999 & 23232921 \\
\hline
\end{tabular}


Çizelge 2. Kahramanmaraş ili ve Türkiye'nin 2008-2013 yıllarındaki tarım alet-makina sayıları

\begin{tabular}{|c|c|c|c|c|c|c|}
\hline \multirow[b]{2}{*}{ lçeler } & \multicolumn{6}{|c|}{ Tarım alet-makina sayısı (adet) } \\
\hline & 2008 & 2009 & 2010 & 2011 & 2012 & 2013 \\
\hline Merkez & 9682 & 10248 & 10666 & 10851 & 11191 & 11474 \\
\hline Afşin & 7122 & 7141 & 7209 & 7287 & 7297 & 7385 \\
\hline Andirın & 5351 & 5351 & 5360 & 5406 & 5484 & 5024 \\
\hline Çağlayancerit & 618 & 617 & 674 & 794 & 815 & 815 \\
\hline Ekinözü & 764 & 762 & 773 & 723 & 702 & 748 \\
\hline Elbistan & 6879 & 11830 & 11954 & 12335 & 19742 & 19093 \\
\hline Göksun & 4708 & 4748 & 4786 & 4882 & 5076 & 5066 \\
\hline Nurhak & 458 & 465 & 470 & 491 & 496 & 364 \\
\hline Pazarcık & 11051 & 11051 & 11145 & 10970 & 9997 & 10598 \\
\hline Türkoğlu & 2101 & 2106 & 2347 & 2347 & 2424 & 2281 \\
\hline Kahramanmaraş & 48734 & 54319 & 55384 & 56086 & 63224 & 62848 \\
\hline Türkiye & 5668827 & 5706448 & 5900152 & 5387943 & 6033140 & 6176658 \\
\hline
\end{tabular}

Çizelge 3. Kahramanmaraş ili ve Türkiye'nin 2008-2013 yıllarındaki traktör sayıları

\begin{tabular}{|c|c|c|c|c|c|c|}
\hline \multirow[b]{2}{*}{ lçeler } & \multicolumn{6}{|c|}{ Traktör sayısı (adet) } \\
\hline & 2008 & 2009 & 2010 & 2011 & 2012 & 2013 \\
\hline Merkez & 1818 & 1835 & 2098 & 2265 & 2340 & 2430 \\
\hline Afşin & 1500 & 1500 & 1500 & 1510 & 1581 & 1595 \\
\hline Andirin & 1327 & 1324 & 1329 & 1337 & 1347 & 1347 \\
\hline Çağlayancerit & 204 & 204 & 232 & 286 & 305 & 320 \\
\hline Ekinözü & 139 & 143 & 138 & 138 & 149 & 162 \\
\hline Elbistan & 2025 & 2132 & 2132 & 2132 & 2904 & 3008 \\
\hline Göksun & 1171 & 876 & 881 & 893 & 904 & 914 \\
\hline Nurhak & 190 & 190 & 191 & 176 & 176 & 114 \\
\hline Pazarcık & 1595 & 1595 & 1633 & 1633 & 1643 & 1643 \\
\hline Türkoğlu & 592 & 582 & 605 & 617 & 625 & 632 \\
\hline Kahramanmaraş & 10561 & 10381 & 10739 & 10987 & 11974 & 12165 \\
\hline Türkiye & 1074529 & 1073029 & 1095521 & 1124795 & 1178049 & 1213374 \\
\hline
\end{tabular}

Çizelge 4. Kahramanmaraş ili ve Türkiye'nin 2008-2013 yıllarındaki toplam traktör gücü değerleri

\begin{tabular}{|c|c|c|c|c|c|c|}
\hline \multirow[b]{2}{*}{ lçeler } & \multicolumn{6}{|c|}{ Toplam traktör gücü $(\mathrm{kW})$} \\
\hline & 2008 & 2009 & 2010 & 2011 & 2012 & 2013 \\
\hline Merkez & 72357 & 73249 & 75959 & 80079 & 83424 & 72357 \\
\hline Afşin & 63200 & 63200 & 63200 & 63826 & 67000 & 67493 \\
\hline Andirın & 55174 & 55040 & 55263 & 55571 & 55968 & 55968 \\
\hline Çağlayancerit & 5948 & 5948 & 6755 & 7473 & 7944 & 7977 \\
\hline Ekinözü & 5398 & 5612 & 5446 & 5446 & 5238 & 5375 \\
\hline Elbistan & 93584 & 98428 & 98428 & 98428 & 139652 & 145075 \\
\hline Göksun & 42643 & 29427 & 29582 & 29960 & 30446 & 30872 \\
\hline Nurhak & 9951 & 9951 & 9956 & 8928 & 8928 & 6153 \\
\hline Pazarcık & 69703 & 69703 & 71383 & 71383 & 71856 & 71856 \\
\hline Türkoğlu & 26500 & 25875 & 26857 & 27379 & 27731 & 28067 \\
\hline Kahramanmaraş & 444457 & 436433 & 442830 & 448472 & 498185 & 491192 \\
\hline Türkiye & 48417020 & 48472748 & 49648293 & 50601172 & 51802035 & 54960783 \\
\hline
\end{tabular}

Tarım alanlarının belirlenmesinde ekili ve nadas alanlarının toplamları dikkate alınmıştır. Tarım aletmakina sayıları, traktörle çalıştırılan alet-makinalar dikkate alınarak belirlenmiştir. Traktör sayıları belirlenirken sadece tekerlekli traktörler dikkate alınmış, paletli traktör sayıları hesaplamalarda kullanılmamıştır. Öncelikle traktörler tek akslı ve çift akslı olarak gruplandırılmış sonrasında her grup içerisinde de güç değerleri dikkate alınarak sınıflandırmalar yapılmıştır (Çizelge 5). Buna bağlı olarak her gruptaki traktör sayısı 
belirlenmiş ve bu değerler toplanarak o yıla ait veriler belirlenmiştir. Çizelge 5'de verilen değerler BG birimi olarak verilmiştir. Hesaplamalar yapılırken bu birim kW'a dönüştürülmüştür. Toplam traktör gücü hesaplamalarında ise her grupta bulunan traktör sayısı o gruba ait ortalama traktör gücü ile çarpılmış ve elde edilen değer toplanarak o yıla ait toplam traktör gücü değeri $\mathrm{kW}$ cinsinden belirlenmiştir.

Çizelge 5. Traktör güç hesaplamasında kullanılan ortalama değerler

\begin{tabular}{lc}
\hline Traktör grubu & Ortalama güç (BG) \\
\hline Tek Akslı (1-5 BG) & 3 \\
Tek Akslı (5 BG'den Fazla) & 7.5 \\
\hline ki Akslı (1-10 BG) & 5.5 \\
ki Akslı (11-24 BG) & 17.5 \\
ki Akslı (25-34 BG) & 29.5 \\
ki Akslı (35-50 BG) & 42.5 \\
ki Akslı (51-70 BG) & 60.5 \\
ki Akslı (70 BG'Den Fazla) & 85 \\
\hline
\end{tabular}

Tarımsal mekanizasyon düzeyi gösterge değerleri, Çizelge 1-4'de verilen değerlerden belirlenmiştir. Veri aralıklarını oluşturabilmek için ilk olarak en küçük ve en büyük veri değerleri arasındaki fark belirlenmiştir. Elde edilen değer beşe (grup sayısı - 1) bölünmüş ve bu değerin yarısı " \pm " olarak en küçük değere eklenmiş ve çıkartılmıştır. Böylece her mekanizasyon düzeyi gösterge değeri kendi içerisinde altı gruba ayrılmıştır.
Örneğin; herhangi bir mekanizasyon gösterge ifadesinin en küçük değerini 5 ve en büyük değeri ise 10 olarak kabul edildiğinde; her iki değer arasındaki fark 5 olup bu değerin altı gruba ayrılabilmesi için 5'e bölünmesinden elde edilen değer de 1 'dir. Bu değerin yarısı da 0.5 olarak bulunur. Buna göre gruplar: en küçük değer $\geq x \leq 5.49 ; 5.5 \geq x \leq 6.49 ; 6.5 \geq x \leq 7.49$; $7.5 \geq \mathrm{x} \leq 8.49 ; 8.5 \geq \mathrm{x} \leq 9.49 ; 9.5 \geq \mathrm{x} \leq$ en büyük değer şeklinde oluşturulur. Haritalar bu gruplar dikkate alınarak oluşturulmuştur. Elde edilen değerlerin bir kısmında en düşük ve en büyük değerlerde farklılıklar oluşmuştur. Bu nedenle bazı haritalar oluşturulurken en düşük değer ve en büyük değer göstergelerinde değişiklikler yapılmıştır. Elde edilen gruplar haritalar üzerinde verilmiştir.

Tarımsal mekanizasyon düzeyi gösterge değerleri aşağıdaki gibi belirlenmiştir:

Birim alana düşen traktör gücü $(k W / h a)$; toplam traktör gücü toplam tarımsal alana oranlanmıştır. 1000 ha alana düssen traktör sayısı (traktör/1000 ha); toplam tarım alanı 1000 ha'a oranlanmış daha sonra elde edilen değer toplam traktör sayısına oranlanmıştır. Traktör başına düşen tarım alanı (ha/traktör); toplam tarım alanı toplam traktör sayısına oranlanmıştır. Traktör başına düşen alet-makina sayısı (alet-makine/traktör); toplam alet-makina sayısı toplam traktör sayısına oranlanmıştır. Ortalama traktör gücü $(k W)$ ise; toplam traktör gücünün toplam traktör sayısına oranlanması ile elde edilmiştir.

Hesaplamalar sonucunda belirlenen tarımsal mekanizasyon düzeyi gösterge değerlerinin sınır değerleri Çizelge 6'da verilmiştir.

Çizelge 6. Tarımsal mekanizasyon düzeyi göstergelerinin sınır değerleri

\begin{tabular}{lc}
\hline Tarımsal mekanizasyon düzeyi göstergesi & Sinır değerler \\
\hline Birim alana düşen traktör gücü (kW/ha) & $0.62-3.77$ \\
1000 ha alana düşen traktör sayısı (traktör /1000 ha) & $19.54-90.66$ \\
Traktör başına düşen tarım alanı (ha/traktör) & $11.03-51.17$ \\
Traktör başına düşen alet-makine sayısı (alet-makine/traktör) & $2.41-6.93$ \\
Ortalama traktör gücü $(\mathrm{kW})$ & $24.93-53.97$ \\
\hline
\end{tabular}

Kahramanmaraş iline ait tarımsal mekanizasyon düzeyi haritaları, ArcGIS 10.1TM yazılımında RMS (Root Mean Square) hatasi 3 metreden az olacak şekilde koordinatlandırılmıştır. Elde edilen görüntü üzerinde $1 / 3000$ - 1/5000 ölçek hassasiyetinde çalışılarak bilgisayar ekranında Kahramanmaraş iline ait harita sayısal ortamda oluşturulmuştur. Kahramanmaraş iline ait öznitelik veri tablosuna gerekli bilgiler (kW/ha, traktör/1000 ha, ha/traktör, alet-makine/traktör ve $\mathrm{kW}$ ) girilmiştir. ArcMap ortamında Reclassify komutu kullanılarak Kahramanmaraş ili için "Birim Alana Düşen Traktör Gücü", "1000 ha Alana Düşen Traktör Sayısı", "Traktör Başına Düşen Tarım Alanı”, "Traktör Başına Düşen Alet/Makina Sayısı" ve "Ortalama Traktör Gücü” haritaları oluşturulmuş ve değerlendirilmiştir.
Tarımsal mekanizasyon gösterge değerlerinin yersel değişimleri ve gruplandırılmasında; kırmızı ile gösterilen hücrelerde bir üst gruba yükselme, mavi ile gösterilen hücrelerde ise alt gruba düşüş olduğunu göstermektedir.

\section{BULGULAR ve TARTISMA}

Birim alana düşen traktör gücü

Kahramanmaraş ilinin ilçeler bazında tarımsal mekanizasyon düzeyi, kW/ha gösterge değeri, 20082013 yıllar itibarı ile; dalgalanmalar göstermiş, genel olarak en yüksek değerler Andırın ilçesinde (2.45-3.75 $\mathrm{kW} / \mathrm{ha}$ ) en düşük değerler ise Göksun ilçesinde (0.66$0.77 \mathrm{~kW} / \mathrm{ha}$ ) belirlenmiştir. Kahramanmaraş ilinin genel ortalaması da yıllar itibarı ile dalgalanmalar (1.21-1.89 kW/ha) göstermiştir. Türkiye'nin genel ortalaması ise yıllar itibarı ile genel olarak artmış ve 
1.98-2.37 kW/ha arasında değişmiştir. (Çizelge 7, Şekil 1). Kahramanmaraş ilinde, birim üretim alanı başına düssen traktör gücü değerlerinin (kW/ha) yıllar itibarı ile dalgalanma göstermesi, gerek üretim alanlarının gerekse traktör sayısının da artması veya azalması ile ilişkili olduğu düşünülmektedir. Türkiye genelinde bu değerin giderek artması, traktör sayısı ve güç değerlerinin artması ve ayrıca çift çeker traktörlerin kullanımının yaygınlaşması ile ilişkili olduğu söylenebilir.

Çizelge 7. Kahramanmaraș ilinde birim alana düşen traktör gücü değerleri

\begin{tabular}{lcccccc}
\hline & \multicolumn{5}{c}{ Birim alana düşen traktör gücü (kW/ha) } \\
\cline { 2 - 6 } lçeler & 2008 & 2009 & 2010 & 2011 & 2012 & 2013 \\
\hline Merkez & 1.11 & 1.10 & 1.17 & 1.28 & 1.44 & 1.31 \\
Afşin & 1.43 & 1.24 & 1.18 & 1.10 & 1.26 & 1.09 \\
Andırın & $\mathbf{2 . 7 0}$ & $\mathbf{2 . 7 2}$ & $\mathbf{2 . 5 3}$ & $\mathbf{2 . 4 5}$ & $\mathbf{3 . 7 7}$ & $\mathbf{2 . 9 7}$ \\
Çağlayancerit & $\mathbf{0 . 6 2}$ & 0.63 & 0.77 & 1.46 & 1.39 & 1.98 \\
Ekinözü & 0.76 & 0.82 & 0.78 & 0.94 & 0.90 & 0.86 \\
Elbistan & 0.94 & 1.28 & 1.22 & 0.99 & 1.75 & 1.44 \\
Göksun & 0.92 & $\mathbf{0 . 6 6}$ & $\mathbf{0 . 6 6}$ & $\mathbf{0 . 6 7}$ & $\mathbf{0 . 6 9}$ & $\mathbf{0 . 7 6}$ \\
Nurhak & 1.99 & 2.43 & 3.35 & 2.73 & 2.87 & 1.95 \\
Pazarcık & 1.48 & 1.32 & 1.33 & 1.31 & 1.62 & 1.45 \\
Türkoğlu & 1.23 & 1.27 & 1.35 & 1.47 & 2.04 & 1.47 \\
\hline Kahramanmaraş & 1.21 & 1.24 & $\mathbf{1 . 8 9}$ & $\mathbf{1 . 1 9}$ & 1.54 & 1.37 \\
\hline Türkiye & $\mathbf{1 . 9 8}$ & 2.03 & 2.18 & 2.14 & 2.18 & $\mathbf{2 . 3 7}$ \\
\hline
\end{tabular}

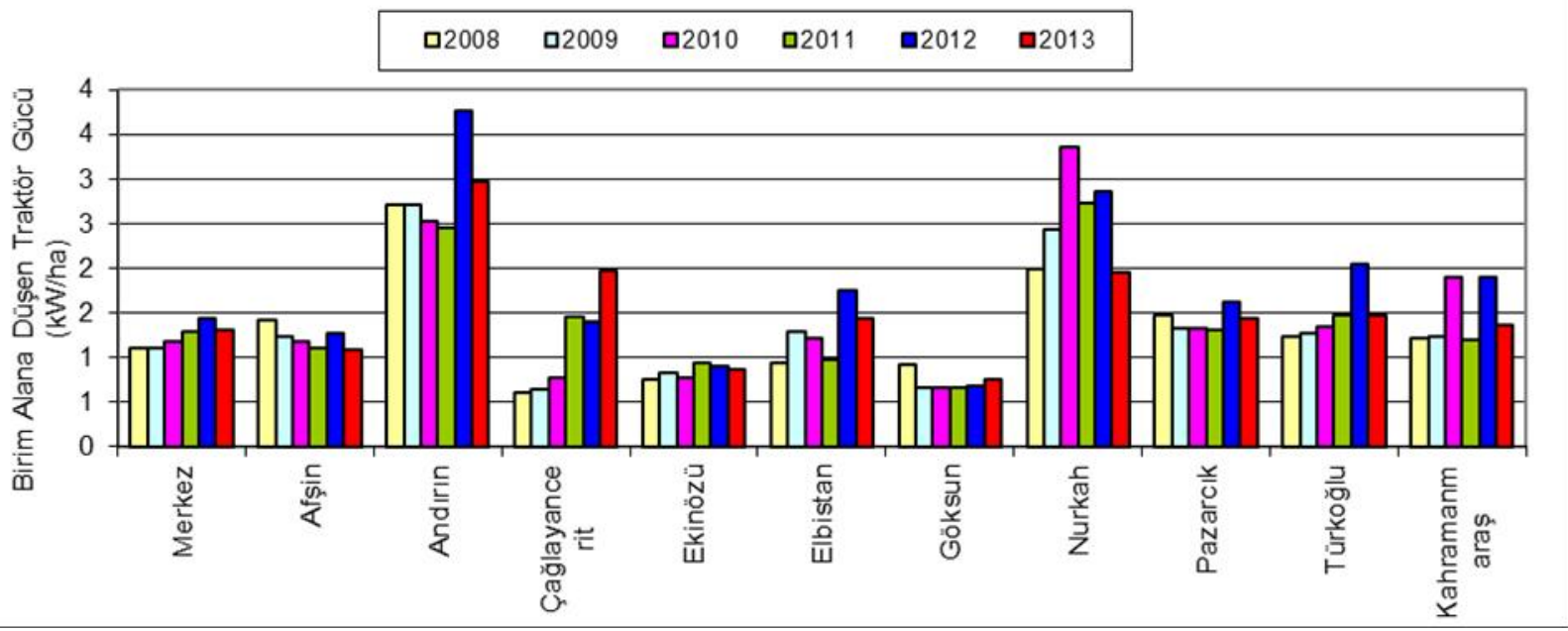

Şekil 1. Kahramanmaraş ilinde birim alana düşen traktör gücünün yıllara ve ilçelere göre grafiksel değişimi

Kahramanmaraş ilinin 2008-2013 yıllarına ait, birim alana düşen traktör gücü $(\mathrm{kW} / \mathrm{ha})$ değerlerinin yersel değişimlerine (Şekil 2) ve gruplandırılmasına (Çizelge 8) bakıldı̆̆ında; 2008 yılında Ekinözü, Göksun, Elbistan ve Çağlayancerit 1. grupta $(0.53-0.97 \mathrm{~kW} / \mathrm{ha})$ yer alırken, Merkez, Afşin ve Türkoğlu 2. grupta (0.98-1.43 $\mathrm{kW} / \mathrm{ha})$, Pazarcik 3. grupta (1.44-1.89 kW/ha), Nurhak 4. grupta (1.90-2.35 kW/ha) ve Andırın ilçesi ise 5 . grupta (2.36-2.81 kW/ha) yer almaktadır. 2009 y1lında Elbistan ve Nurhak bulundukları gruplardan bir üst gruba yükselirken Pazarcık ilçesi bir alt gruba düşmüştür. 2008 yılı ile karşılaştırıldı̆̆ında; 2013 yılında Çağlayancerit (1.90-2.35 kW/ha), Andırın (2.82$3.27 \mathrm{~kW} / \mathrm{ha})$, Elbistan ve Türkoğlu (1.44-1.89 kW/ha) ilçeleri üst gruplara yükselirken diğer ilçeler değişmemiştir. 

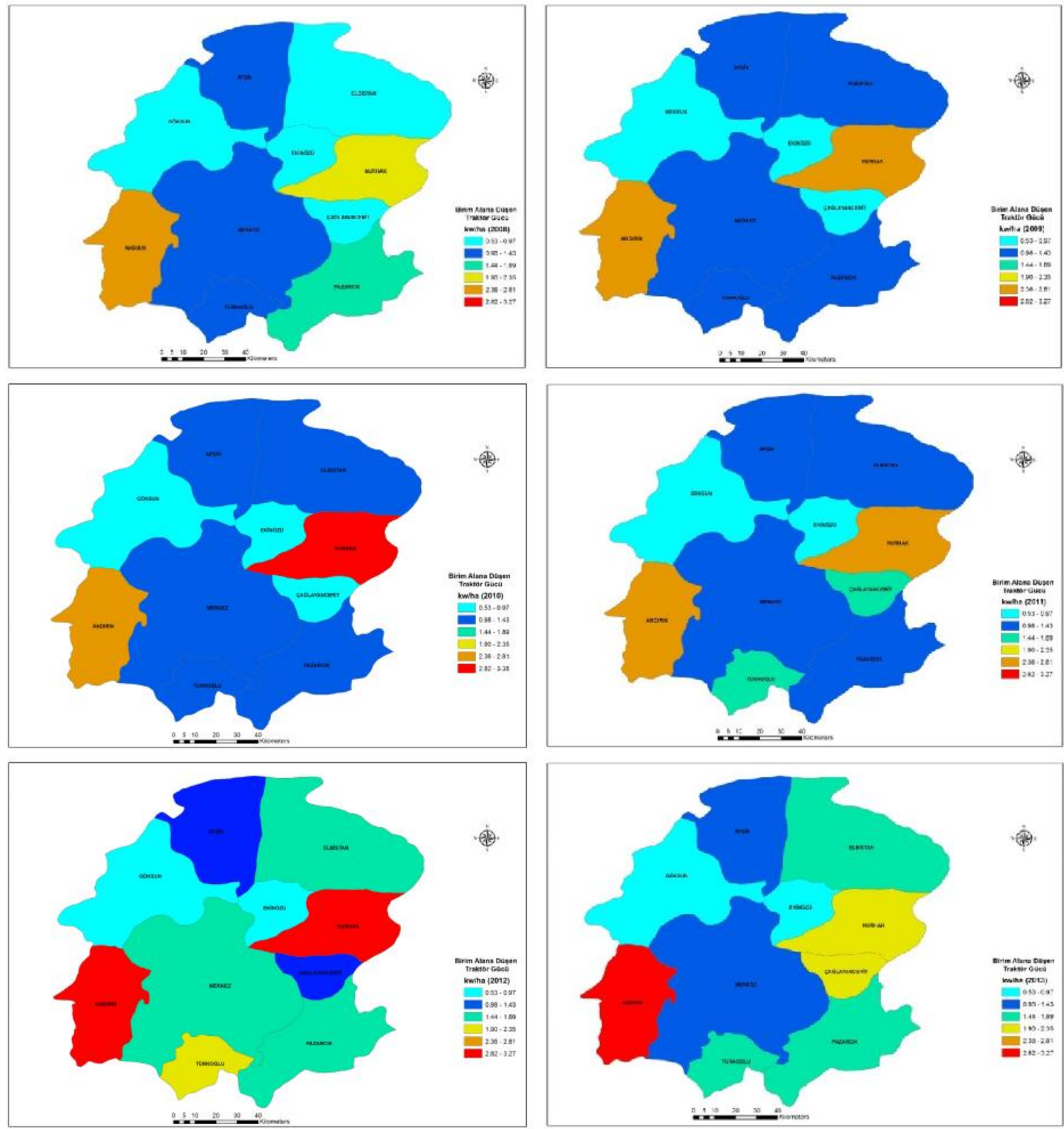

Şekil 2. Kahramanmaraş ilinde birim alana düşen traktör gücü değerlerinin yıllara göre yersel dağılımı

Çizelge 8. Birim alana düşen traktör gücü değerlerinin yersel değişim grupları

\begin{tabular}{lcccccc} 
& \multicolumn{7}{c}{ Grup numaraları } \\
\cline { 2 - 7 } lçeler & 2008 & 2009 & 2010 & 2011 & 2012 & 2013 \\
\hline Merkez & 2 & 2 & 2 & 2 & 3 & 2 \\
Afşin & 2 & 2 & 2 & 2 & 2 & 2 \\
Andırın & 5 & 5 & 5 & 5 & 6 & 6 \\
Çağlayancerit & 1 & 1 & 1 & 3 & 2 & 4 \\
Ekinözü & 1 & 1 & 1 & 1 & 1 & 1 \\
Elbistan & 1 & 2 & 2 & 2 & 3 & 3 \\
Göksun & 1 & 1 & 1 & 1 & 1 & 1 \\
Nurhak & 4 & 5 & 6 & 5 & 6 & 4 \\
Pazarcik & 3 & 2 & 2 & 2 & 3 & 3 \\
Türkoğlu & 2 & 2 & 2 & 3 & 4 & 3 \\
\hline
\end{tabular}




\section{0 ha alana düsen traktör sayıst}

1000 ha alana düşen traktör sayısı değerleri (traktör/1000 ha); 2008-2013 yıllarında genel olarak hem Kahramanmaraş il genelinde hem de ilçeler bazında dalgalanmalar göstermiş. En yüksek değerler Andırın ilçesinde (58-90 traktör/1000 ha), en düşük değerler ise Ekinözü (19-25 traktör/1000 ha) ve Göksun ilçelerinde (19-22 traktör/1000 ha) gerçekleşmiştir. Kahramanmaraş geneli ise 29-37 traktör/1000 ha olmaktadır. Türkiye genel ortalaması (44-52 traktör/1000 ha) yıllar itibari ile artmıştır (Çizelge 9; Şekil 3).

Çizelge 9. Kahramanmaraş ilinde 1000 ha alana düşen traktör sayısı değerleri

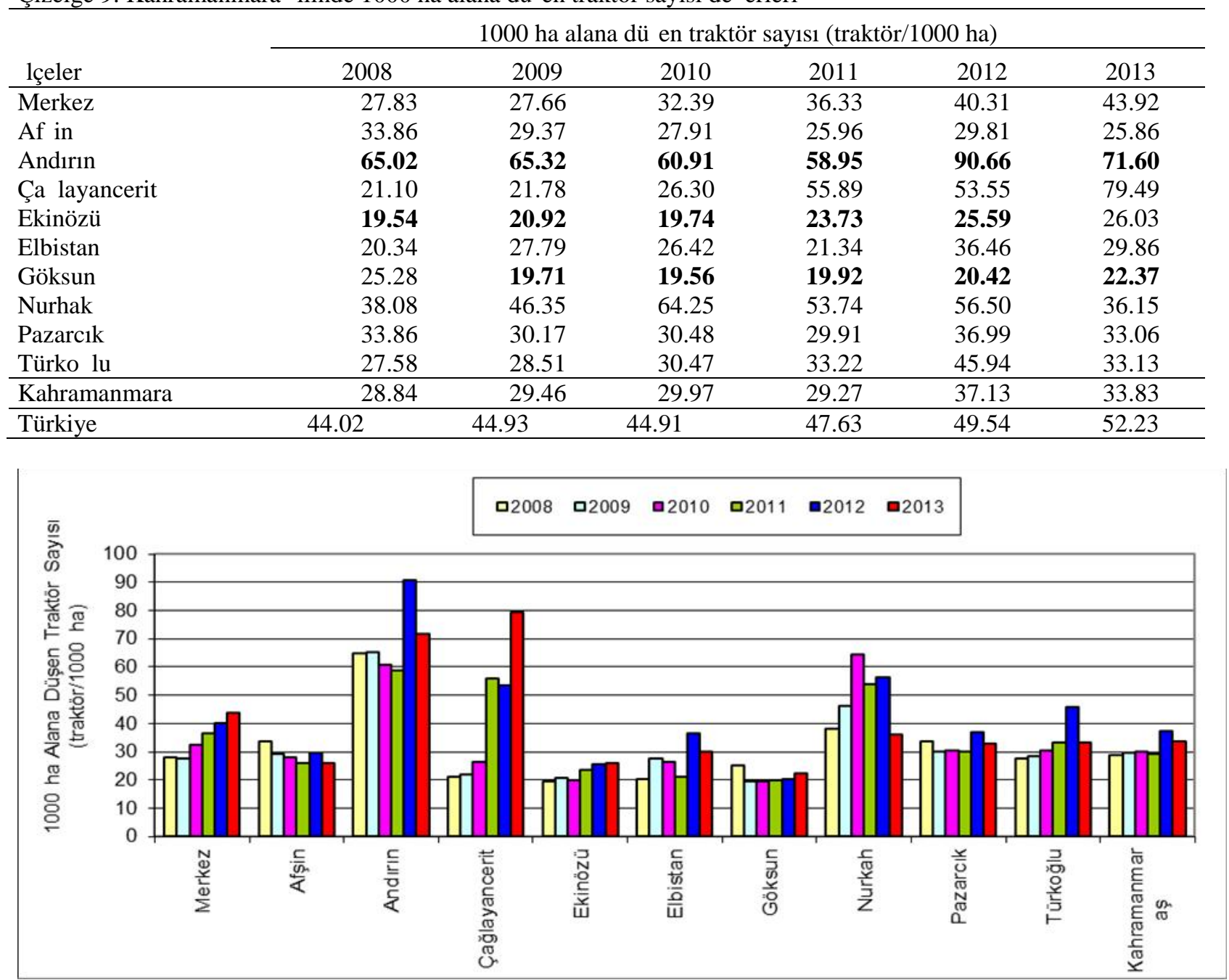

Şekil 3. Kahramanmaraş ilinde 1000 ha alana düşen traktör sayısının yıllara göre grafiksel değişimi

Kahramanmaraș ilinde, 2008-2013 yıllarına ait, 1000 ha alana düşen traktör sayısı (traktör/1000 ha) yersel değişimlerine (Şekil 4) ve gruplandırılmasına (Çizelge 10) bakıldığında; 2008 yılında Merkez, Çağlayancerit, Ekinözü, Elbistan, Göksun ve Türkoğlu ilçeleri 1. grupta (16-30 traktör/1000 ha) yer alırken, Afşin, Nurhak ve Pazarcık ilçeleri 2. grupta (31-45 traktör/1000 ha), Andırın ise 4. grupta (61-65 traktör/1000 ha) yer almaktadır. 2008 yılı ile karşılaştırıldığında; 2013 yılında Merkez ve Türkoğlu ilçeleri bir üst gruba, Çağlayancerit ilçesi ise 5. gruba (76-90 traktör/1000 ha) yükselmiş, Afşin ilçesi ise bir alt gruba düşmüştür. Diger ilçelerde bir degişim olmamıştır. 

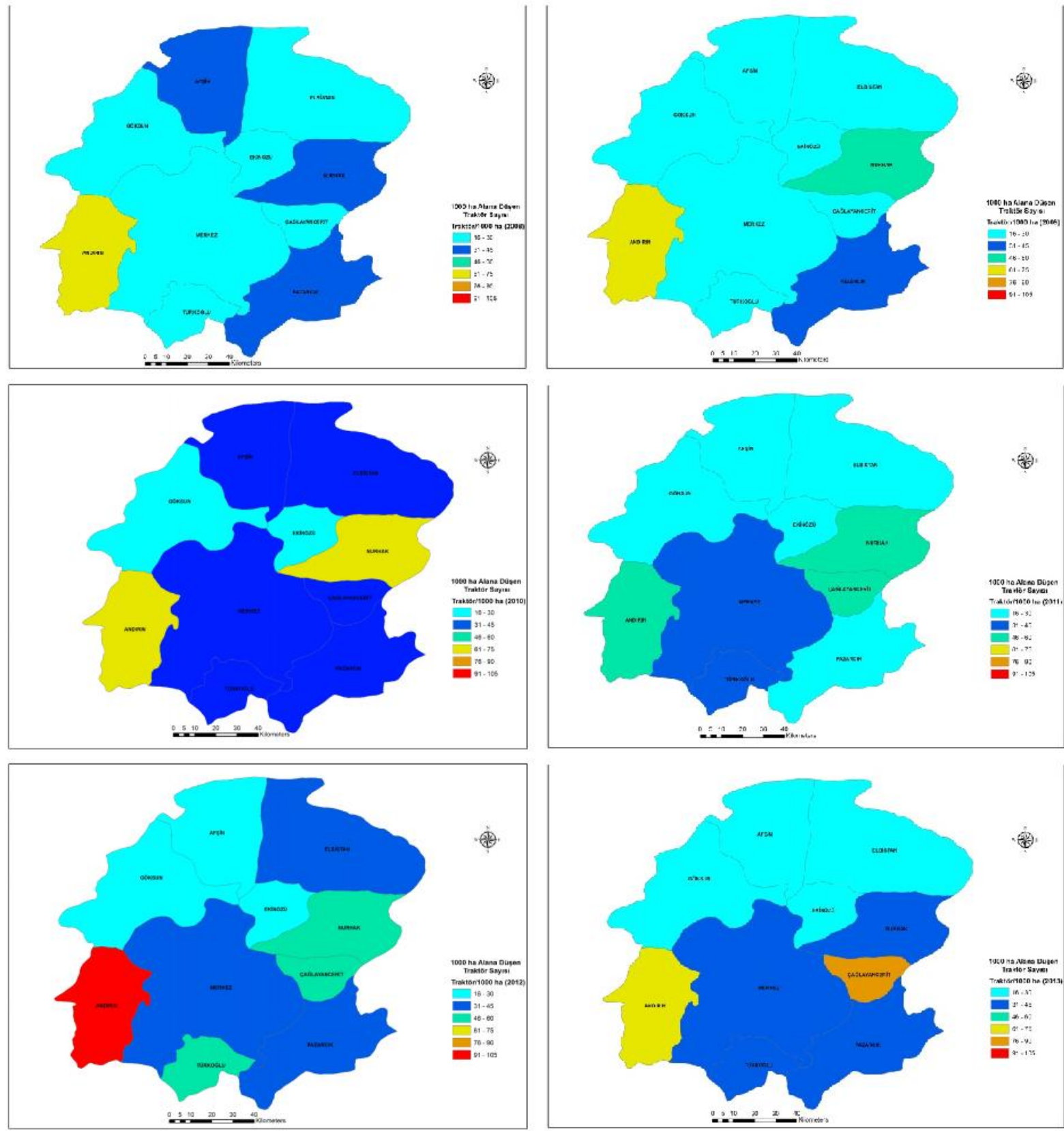

Şekil 4. Kahramanmaraş ilinde 1000 ha alana düşen traktör sayısının yıllara göre yersel dağılımı

Çizelge 10. 1000 ha alana düşen traktör sayısı değerlerinin yersel değişim grupları

\begin{tabular}{lcccccc}
\hline & \multicolumn{7}{c}{ Grup numaraları } \\
\cline { 2 - 7 } lçeler & 2008 & 2009 & 2010 & 2011 & 2012 & 2013 \\
\hline Merkez & 1 & 1 & 2 & 2 & 2 & 2 \\
Afşin & 2 & 1 & 2 & 1 & 1 & 1 \\
Andırın & 4 & 4 & 4 & 3 & 6 & 4 \\
Çağlayancerit & 1 & 1 & 2 & 3 & 3 & 5 \\
Ekinözü & 1 & 1 & 1 & 1 & 1 & 1 \\
Elbistan & 1 & 1 & 2 & 1 & 2 & 1 \\
Göksun & 1 & 1 & 1 & 1 & 1 & 1 \\
Nurhak & 2 & 3 & 4 & 3 & 3 & 2 \\
Pazarcık & 2 & 2 & 2 & 1 & 2 & 2 \\
Türkoğlu & 1 & 1 & 2 & 2 & 3 & 2 \\
\hline
\end{tabular}




\section{Traktör bașına düssen tarım alanı}

Traktör başına düșen tarım alanı değerleri (ha/traktör), 2008-2013 yılarında; hem Kahramanmaraş il genelinde hem de ilçeler bazında, genel olarak dalgalanmalar göstermekte, Türkiye genelinde ise azalmaktadır (Çizelge 11, Şekil 5). Traktör başına düşen tarım alanı (ha/traktör) değerinin azalması, mekanizasyon düzeyinin arttı̆̆ını göstermektedir. Ortalama traktör başına düşen tarım alanı, Kahramanmaraş il genelinde 26.93-34.68 ha/traktör, Türkiye genelinde ise 19.15-22.71 ha/traktör olmaktadır.

Çizelge 11. Kahramanmaraş ilinde traktör baş̧ına düşen tarım alanı değerleri

\begin{tabular}{|c|c|c|c|c|c|c|}
\hline \multirow[b]{2}{*}{ lçeler } & \multicolumn{6}{|c|}{ Traktör başına düşen tarım alanı (ha/traktör) } \\
\hline & 2008 & 2009 & 2010 & 2011 & 2012 & 2013 \\
\hline Merkez & 35.93 & 36.15 & 30.88 & 27.52 & 24.81 & 22.77 \\
\hline Afşin & 29.53 & 34.05 & 35.83 & 38.52 & 33.54 & 38.66 \\
\hline Andirın & 15.38 & 15.31 & 16.42 & 16.96 & 11.03 & 13.97 \\
\hline Çağlayancerit & 47.39 & 45.92 & 38.02 & 17.89 & 18.68 & 12.58 \\
\hline Ekinözü & 51.17 & 47.80 & 50.66 & 42.14 & 39.07 & 38.42 \\
\hline Elbistan & 49.16 & 35.98 & 37.85 & 46.87 & 27.43 & 33.49 \\
\hline Göksun & 39.56 & 50.72 & 51.13 & 50.19 & 48.96 & 44.70 \\
\hline Nurhak & 26.26 & 21.57 & 15.56 & 18.61 & 17.70 & 27.66 \\
\hline Pazarcık & 29.53 & 33.15 & 32.81 & 33.43 & 27.04 & 30.25 \\
\hline Türkoğlu & 36.26 & 35.07 & 32.82 & 30.11 & 21.77 & 30.19 \\
\hline Kahramanmaraş & 34.68 & 33.95 & 33.37 & 34.16 & 26.93 & 29.56 \\
\hline Türkiye & 22.71 & 22.26 & 22.27 & 20.99 & 20.19 & 19.15 \\
\hline
\end{tabular}

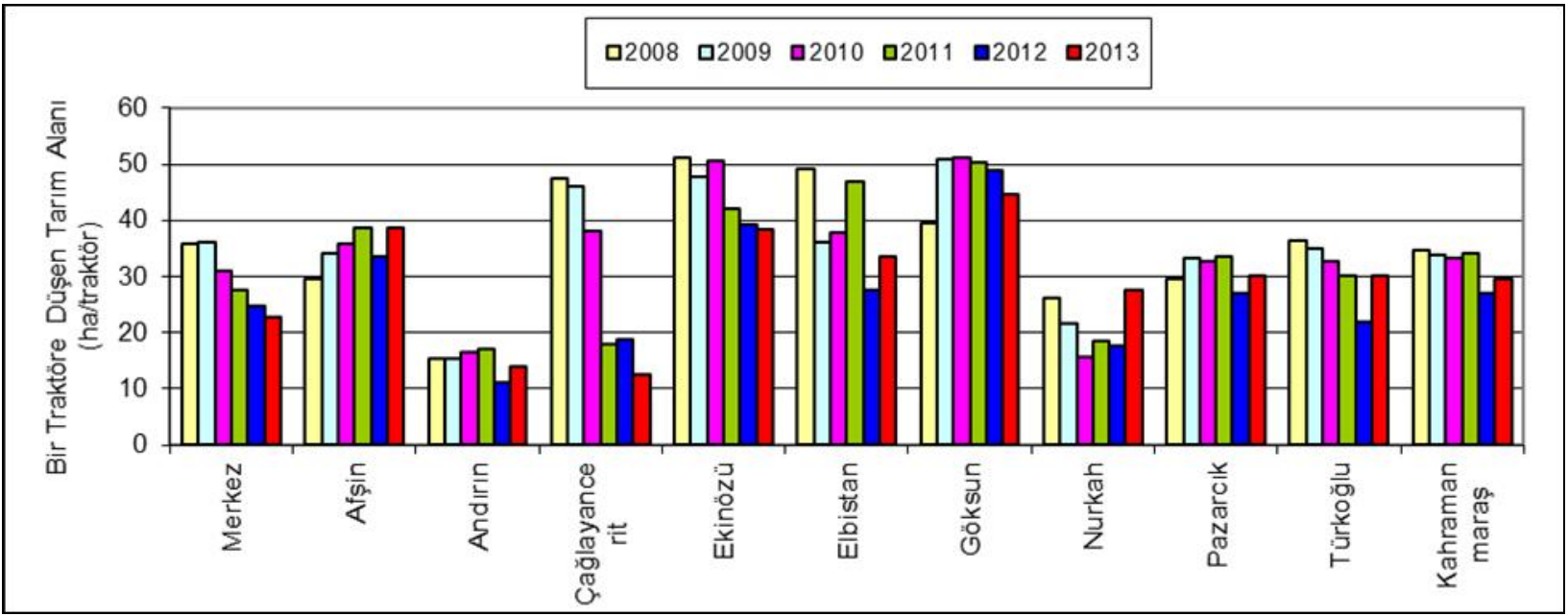

Şekil 5. Kahramanmaraş ilinde traktör başına düşen tarım alanının yıllara göre grafiksel değişimi

Kahramanmaraș ilinin, 2008-2013 yıllarına ait, traktör başına düşen tarım alanı (ha/traktör) yersel değişimlerine (Şekil 6) ve gruplandırılmasına (Çizelge 12) bakıldığında; 2008 yılında, Andırın ilçesi 1. grupta (12-18 ha/traktör), Nurhak ilçesi 2. grupta (19-27 ha/traktör), Merkez, Afşin ve Pazarcık ilçeleri 3. grupta (28-36 ha/traktör), Göksun ve Türkoğlu ilçeleri 4. grupta (37-45 ha/traktör), Çağlayancerit, Ekinözü ve Elbistan lçeleri 5. grupta (46-54 ha/traktör) yer almaktadır. 2008 yılı ile karşılaştırıldığında; 2013 yılında, Merkez, Çağlayancerit, Ekinözü, Elbistan, Göksun ve Türkoğlu alt gruplara inerken, Afşin ve Nurhak ilçeleri üst gruplara yükselmişler, diğer ilçeler ise değişmemiştir. 

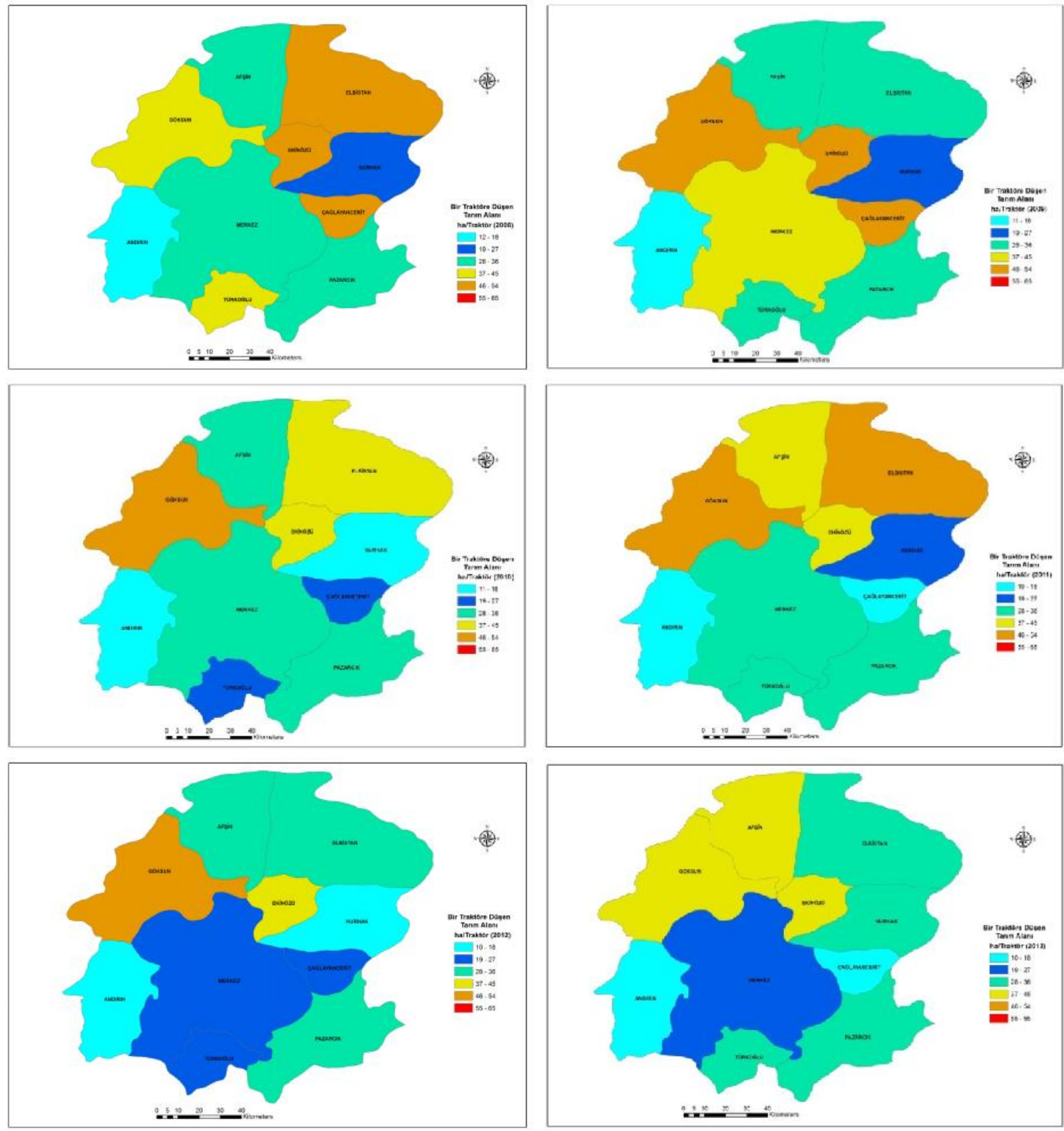

Şekil 6. Kahramanmaraş ilinde traktör başına düşen tarım alanı değerlerinin yıllara göre yersel dağılımı

Çizelge 12. Traktör başına düşen tarım alanını değerlerinin yersel değişim grupları

\begin{tabular}{lcccccc}
\hline & \multicolumn{7}{c}{ Grup numaraları } \\
\cline { 2 - 7 } lçeler & 2008 & 2009 & 2010 & 2011 & 2012 & 2013 \\
\hline Merkez & 3 & 4 & 3 & 3 & 2 & 2 \\
Afşin & 3 & 3 & 3 & 4 & 3 & 4 \\
Andırın & 1 & 1 & 1 & 1 & 1 & 1 \\
Çağlayancerit & 5 & 5 & 2 & 1 & 2 & 1 \\
Ekinözü & 5 & 5 & 4 & 4 & 4 & 4 \\
Elbistan & 5 & 3 & 4 & 5 & 3 & 3 \\
Göksun & 4 & 5 & 5 & 5 & 5 & 4 \\
Nurhak & 2 & 2 & 1 & 2 & 1 & 3 \\
Pazarcık & 3 & 3 & 3 & 3 & 3 & 3 \\
Türkoğlu & 4 & 3 & 2 & 3 & 2 & 3 \\
\hline
\end{tabular}


Traktör başına düşen alet-makine sayısı

Traktör başına düşen tarım alet-makine sayısı (aletmakine/traktör) değerleri, 2008-2013 yılarında; hem Kahramanmaraş il geneli hem ilçeler bazında, hem de Türkiye genelinde, genel olarak değişiklik göstermektedir. Alet-makine/traktör gösterge değeri; en yüksek (6.08-6.93 alet-makine/traktör) Pazarcık ilçesinde, en düşük (2.55-3.03 alet-makine/traktör) Çağlayancerit ilçesinde olmaktadır. Türkiye genelinde ise 4.79-5.32 alet/makine/traktör değerleri belirlenmiştir (Çizelge 13, Şekil 7).

Çizelge 13. Kahramanmaraş ilinde traktör başına düşen alet-ekipman sayısı değerleri

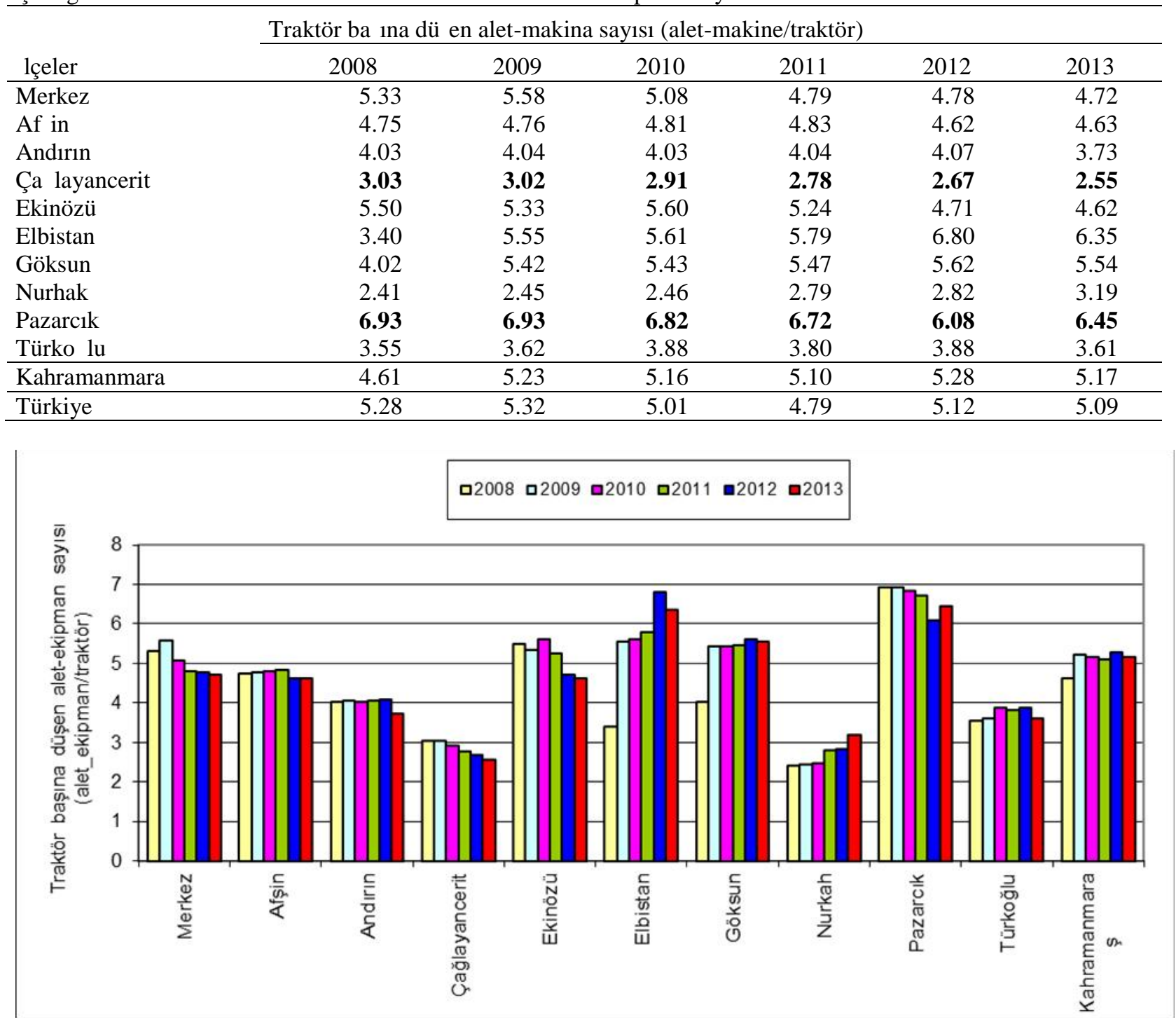

Şekil 7. Kahramanmaraş ilinde traktör başına düşen alet-makina sayısının yıllara göre grafiksel değişimi

Traktör başına düşen alet-makina sayısı (aletmakine/traktör) değerlerinin yersel değişimlerine (Şekil 8) ve gruplandırılmasına (Çizelge 14) bakıldığında; 2008 yılında sadece Pazarcık ilçesi 2. grupta (5.6-7.1 alet-makine/traktör) yer alırken, diğer tüm ilçeler 1 . grupta (2.4-5.5 alet-makine/traktör) yer almışlardır. lerleyen y1llarda sadece Elbistan ve Göksun ilçeleri bir üst grup olan 2. gruba yükselmiş, diğer ilçelerde bir değişiklik olmamıştır. 

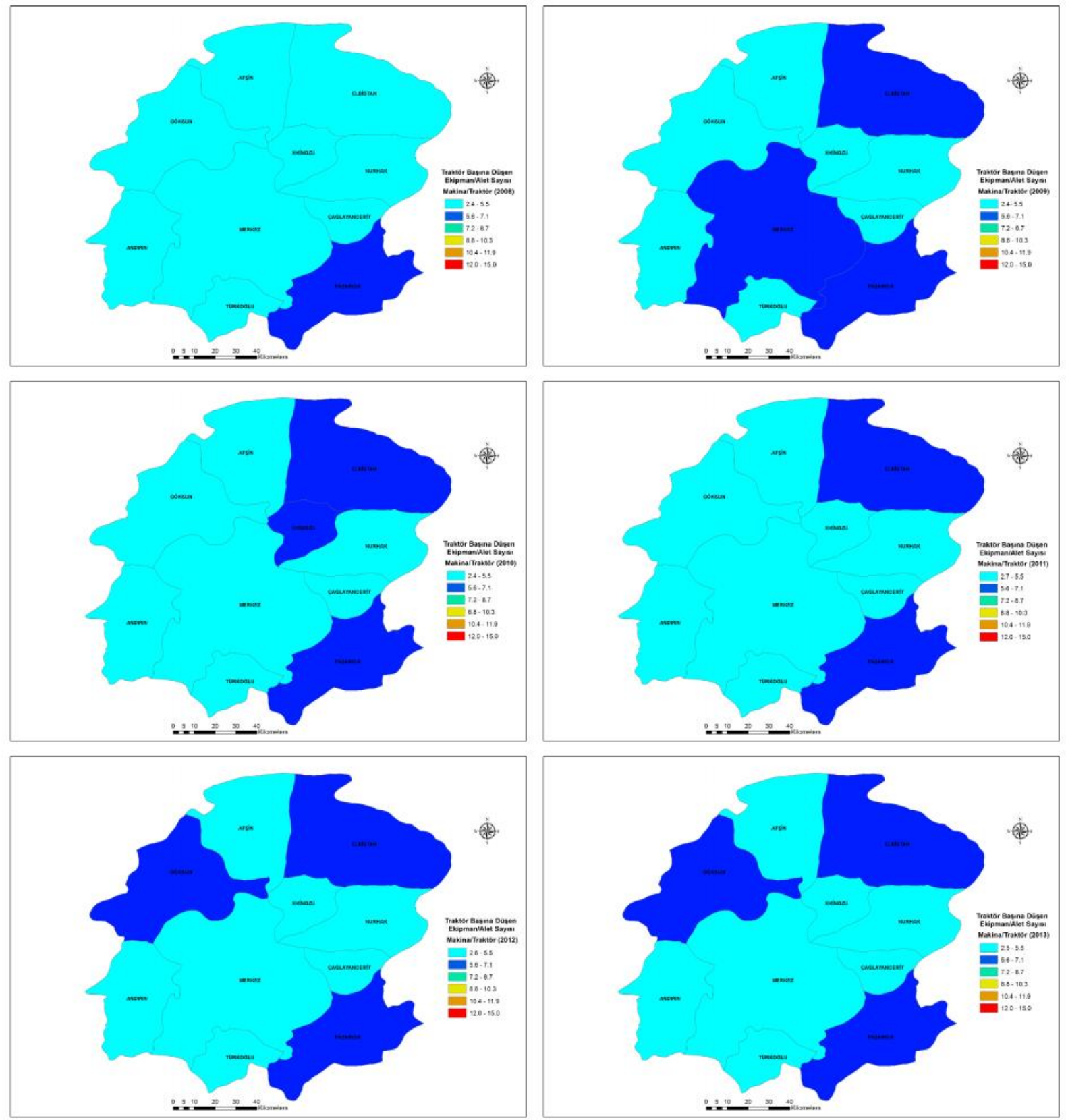

Şekil 8. Kahramanmaraş ilinde traktör başına düşen ekipman/alet sayısınin yıllara göre yersel dagılımı

Çizelge 14. Traktör başına düşen alet-ekipman sayısı değerlerinin yersel değişim grupları

\begin{tabular}{lcccccc}
\hline & \multicolumn{7}{c}{ Grup numaraları } \\
\cline { 2 - 7 } lçeler & 2008 & 2009 & 2010 & 2011 & 2012 & 2013 \\
\hline Merkez & 1 & 2 & 1 & 1 & 1 & 1 \\
Afşin & 1 & 1 & 1 & 1 & 1 & 1 \\
Andırın & 1 & 1 & 1 & 1 & 1 & 1 \\
Çağlayancerit & 1 & 1 & 1 & 1 & 1 & 1 \\
Ekinözü & 1 & 1 & 2 & 1 & 1 & 1 \\
Elbistan & 1 & 2 & 2 & 2 & 2 & 2 \\
Göksun & 1 & 1 & 1 & 1 & 2 & 2 \\
Nurhak & 1 & 1 & 1 & 1 & 1 & 1 \\
Pazarckk & 2 & 2 & 2 & 2 & 2 & 2 \\
Türkoğlu & 1 & 1 & 1 & 1 & 1 & 1 \\
\hline
\end{tabular}




\section{Ortalama traktör gücü}

Ortalama traktör gücü $(\mathrm{kW})$; 2008-2013 yıllarında, hem Kahramanmaraş il genelinde, hem ilçeler bazında hem de Türkiye genelinde, genel olarak değişiklik göstermektedir. En yüksek değerler Elbistan ilçesinde (46-48 kW), en düşük değerler Çağlayancerit ilçesinde (24-29 kW) belirlenmiștir. Ortalama traktör gücü,
Kahramanmaraş il genelinde 40-42 kW, Türkiye genelinde ise $44-45 \mathrm{~kW}$ olmaktadır (Çizelge 15, Şekil 9). Ortalama traktör gücü değerlerinin yüksek olması, çift çeker traktörlerin kullanım oranıyla ilişkili olmaktadır. Buna göre son yıllarda sadece Göksun ilçesinde az sayıda da olsa çift çeker traktörlerinde bir artış olduğu, söylenebilir.

Çizelge 15. Kahramanmaraş ilinde ortalama traktör gücü değerleri

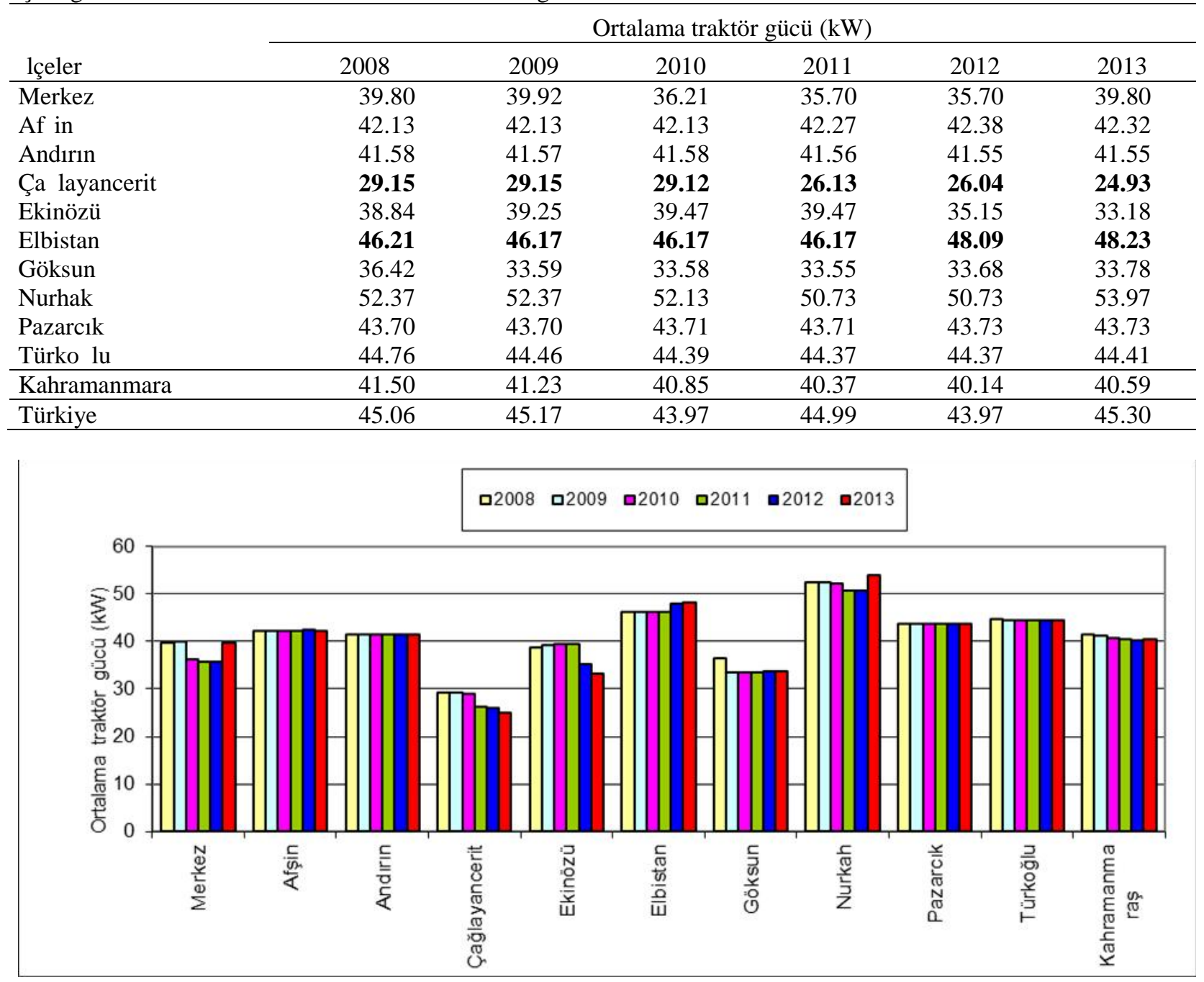

Şekil 9. Kahramanmaraş ilinde ortalama traktör gücünün yıllara göre grafiksel değişimi

Ortalama traktör gücü $(\mathrm{kW})$ değerlerinin yersel değişimlerine (Şekil 10) ve gruplandırılmasına (Çizelge 16) bakıldığında; 2008 yılında Çağlayancerit 1 . Grupta (29.2-31.5 kW), Göksun 3. Grupta (34.9-38.1 kW), Merkez ve Ekinözü 4. Grupta (38.2-41.4 kW), Afşin,
Andırın ve Pazarcık 5. Grupta (41.5-44.7), Elbistan ve Türkoğlu ilçeleri ise 6. Grupta $(44.8-55 \mathrm{~kW})$ yer almaktadır. 2009-2013 yıllarında ise genel olarak Ekinözü, Göksun ve Türkoğlu bir alt grup/gruplara düşmüşler, diğer ilçelerde bir değişiklik olmamıştır. 

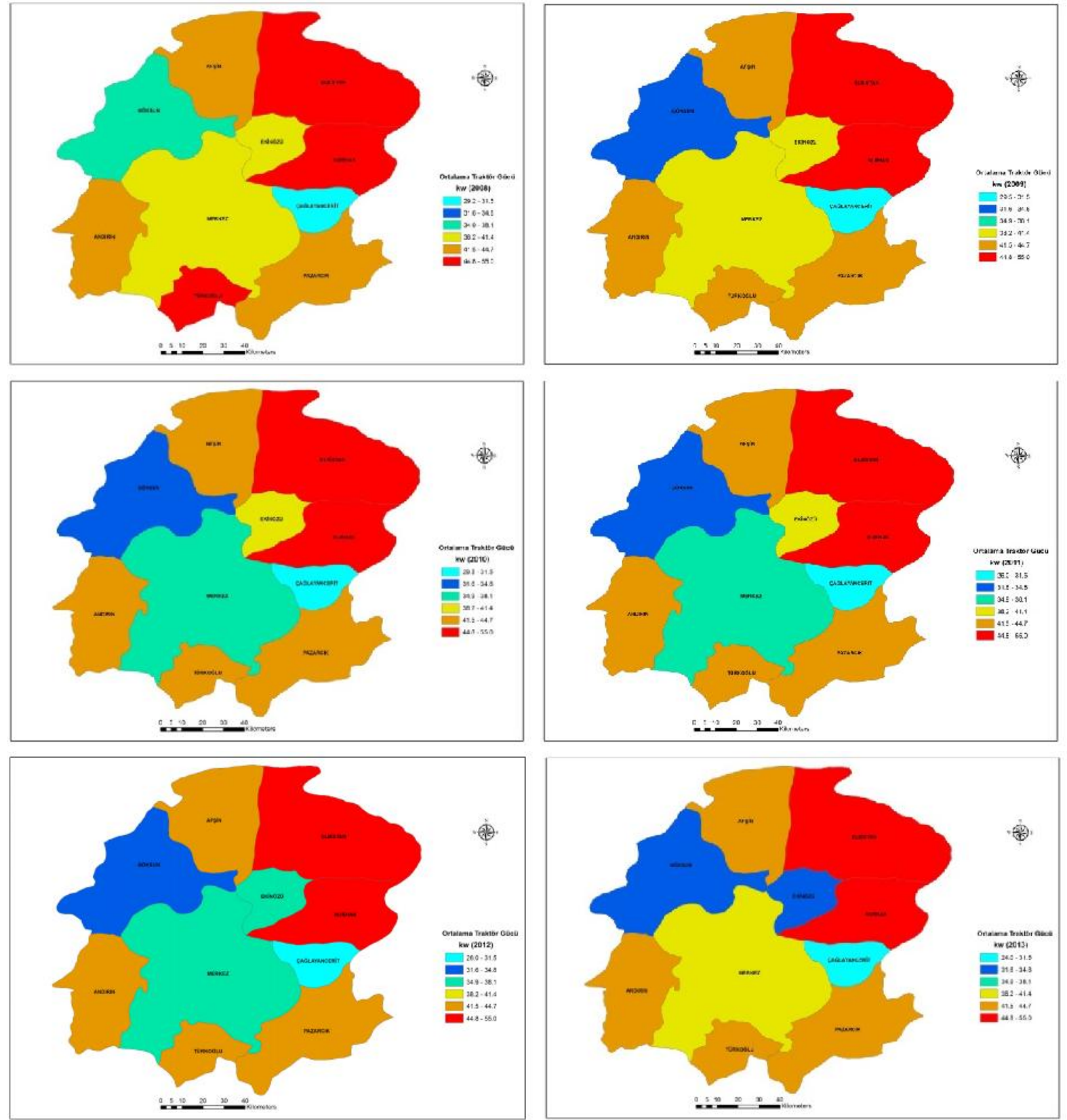

Şekil 10. Kahramanmaraş ilinde ortalama traktör gücü değerlerinin yıllara göre yersel dağılımı

Çizelge 16. Ortalama traktör gücü değerlerinin yersel değişim grupları

\begin{tabular}{lcccccc} 
& \multicolumn{7}{c}{ Grup numaraları } \\
\cline { 2 - 7 } lçeler & 2008 & 2009 & 2010 & 2011 & 2012 & 2013 \\
\hline Merkez & 4 & 4 & 3 & 3 & 3 & 4 \\
Afşin & 5 & 5 & 5 & 5 & 5 & 5 \\
Andırın & 5 & 5 & 5 & 5 & 5 & 5 \\
Çağlayancerit & 1 & 1 & 1 & 1 & 1 & 1 \\
Ekinözü & 4 & 4 & 4 & 4 & 3 & 2 \\
Elbistan & 6 & 6 & 6 & 6 & 6 & 6 \\
Göksun & 3 & 2 & 2 & 2 & 2 & 2 \\
Nurhak & 6 & 6 & 6 & 6 & 6 & 6 \\
Pazarcık & 5 & 5 & 5 & 5 & 5 & 5 \\
Türkoğlu & 6 & 5 & 5 & 5 & 5 & 5 \\
\hline
\end{tabular}




\section{SONUÇLAR}

$\mathrm{Bu}$ çalışmada elde edilen sonuçlar aşağıdaki gibi özetlenebilir.

1. 2008-2013 yıllarında, Kahramanmaraş il geneli ve ilçeler bazında, tarımsal mekanizasyon düzeyi gösterge değerleri, genel olarak dalgalanmalar göstermiştir. $\mathrm{Bu}$ dalgalanmalar, yıllar itibarı ile üretim alanlarının ve traktör sayılarının artması veya azalmasından kaynaklanmıştır.

2. lin tarımsal mekanizasyon düzeyi değerleri Türkiye genel ortalamasından düşük bulunmuştur.

3. Kahramanmaraş ilinin mekanizasyon düzeyi gösterge değerleri ortalaması, $1.21-1.37 \mathrm{~kW} / \mathrm{ha}$, 28.84-33.83 traktör/1000 ha, 34.68-29.56 ha/traktör ve 4.61-5.17 alet-makine/traktör'dür.

4. kW/ha gösterge değeri, en yüksek Andırın ilçesinde (2.45-3.75 kW/ha) en düşük ise Göksun ilçesinde (0.66-0.77 kW/ha) oluşmuştur.

5. Traktör/1000 ha gösterge değeri; en yüksek Andırın ilçesinde (58-90 traktör/1000 ha), en düşük ise Ekinözü (19-25 traktör/1000 ha) ve Göksun ilçelerinde (19-22 traktör/1000 ha) gerçekleşmiştir.

6. ha/traktör gösterge değeri; en düşük Çağlayancerit ilçesinde (12.58 ha/traktör), en yüksek ise Göksun ilçesinde (44.70 ha/traktör) belirlenmiştir.

7. Alet-makine/traktör gösterge değeri; en yüksek Pazarcık ilçesinde (6.45 alet-makine/traktör), en düşük ise Çağlayancerit ilçesinde (2.55 aletmakine/traktör) gerçekleşmiştir.

8. Kahramanmaraş il genelinde ortalama traktör gücü değeri 41.5-40.59 kW olmaktadır.

9. Kahramanmaraş ilinin ilçeler bazında tarımsal mekanizasyon gösterge değerlerinin yersel değişimleri ve gruplandırılmasında; kırmızı ile gösterilen hücrelerde bir üst gruba yükselme, mavi ile gösterilen hücrelerde ise alt gruba düşüş olduğunu göstermektedir.

\section{KAYNAKLAR}

Anonim, 1999. Machinery Management. How to Select Machinery to Fit The Needs of Today's Farm Managers. John Deere Publishing, Almon-TIAC Building, Suite 140, 1300 19th Street, East Moline, IL 61244.

Anonim, 2000. Tarım Alet ve Makinaları Sanayii ve Rekabet Edebilirlik Özel htisas Komisyonu Raporu (Sekizinci Beş Yıllık Kalkınma Planı). TC Başbakanlık Devlet Planlama Teşkilatı, Ankara.

Anonim, 2014. Kahramanmaraş 1 Gıda Tarım ve Hayvancilık Müdürlüğü http://kahramanmaras.tarim.gov.tr/Menu/25/Kahraman maras.
Atay, S., Işık, A., 1997. Kahramanmaraş ilinde tarım işletmelerinin tarımsal yapı ve mekanizasyon özellikleri. Tarımsal Mekanizasyon 17. Ulusal Kongresi, s.55-67. Tokat.

Aybek, A., Hurşitoğlu, Ç., 2002. Kahramanmaraş Yöresi Tarım şletmelerinin Mekanizasyon Özellikleri ve Bu Özellikler Arası lişkiler. KSÜ Fen ve Mühendislik Dergisi, 5(2): 105-113, Kahramanmaraş.

Aybek, A., Şenel, H., 2009. Mechanization properties and users'evaluation of farm tractors in Eastern Mediterranean Turkey. Tarım Makineları Bilimi Dergisi, 5(1):21-27.

Dartar, . 2007. Türkiye'nin tarımsal Mekanizasyon Düzeyinin Değerlendirilmesi ve Coğrafi Bilgi Sistemleri ile Haritalanması. Çukurova Üniversitesi Fen Bilimleri Enstitüsü, Yüksek Lisans Tezi, 62 sayfa.

Elmas, C., Tuncer, .K., Kirişçi, V., Demir, L., 1995. Kahramanmaraş ilinin tarımsal mekanizasyon düzeyi ve sorunları. Tarımsal Mekanizasyon 16. Ulusal Kongresi, s.35-44, Bursa.

Ergüneş, G., Tarhan, S., Yardım, M.H., Kasap, A., Demir, F., Önal, ., Uçar, T., Tekelioğlu, O., Çalışır, S., Yumak, H., Yağcıoğlu, A. 2009. Tarım Makinaları. Nobel Bilim ve Araştırma Merkezi, Yayın No:49, Ankara. 544s.

Evcim, H., Ü., Ulusoy, E., Gülsoylu, E., Tekin, B., 2010. Tarımsal mekanizasyon durumu sorunları ve çözüm önerileri. Türkiye Ziraat Mühendisleri 7. Teknik Kongresi Bildiriler Kitabi-2 s. 989-1007. Ankara

Ozan, E., 2001. Yeni Bin Y1lın Eşiğinde Kahramanmaraş'ın Sosyoekonomik Yapısı. Kahramanmaraş Ticaret ve Sanayi Odası, Yaşar Ofset Matbaacılık, Kahramanmaraş.

Sabanc1, A., Akınc1, ., 1994. Dünyada ve Türkiye'de Tarımsal Mekanizasyon Düzeyi ve Son Gelişmeler. Tarımsal Mekanizasyon 15. Ulusal Kongresi, pp:404415, Antalya.

Say, S.M., Sabanc1, A., Başçetinçelik, A., Özgüven, F., Öztürk, H. H., 2010. Tarım Makinaları 1. Nobel Kitabevi Yayın dağıtım ve Pazarlama Ltd. Şti. Adana.

Toğa, N., 2006. Ülkemizin Tarımsal Mekanizasyon Durumu, Sorunları ve Çözüm Önerileri. Tarımsal Mekanizasyon 23. Ulusal Kongresi, 6-8 Eylül, Çanakkale.

TUIK, 2014. Türkiye statistik Kurumu. Tarımsal statistik Verileri. http://www.tuik.gov.tr/ (Erişim tarihi: Mayıs 2014).

Zeren, Y., Tezer, E., Tuncer, .K., Evcim, Ü., Güzel, E., Sındır, K.O., 1995. Tarım Alet-Makine ve Ekipman Kullanım ve Üretim Sorunları. Ziraat Mühendisliği Teknik Kongresi Tarım Haftası 95 Kongresi, 9-13 Ocak 1995, Ankara. 